\title{
Penurunan Kadar COD, BOD dan Nitrit Limbah Pabrik Tahu Menggunakan Karbon Aktif Ampas Bubuk Kopi
}

\author{
Zulhaini Sartika1*, Mariana2, M. Dani Supardan3 \\ 1Prodi Teknik Kimia Universitas Serambi Mekkah \\ 2,3 Prodi Magister Teknik Kimia Universitas Syiah Kuala \\ *Koresponden email : zulhaini.sartika@serambimekkah.ac.id
}

Diterima : 4 April 2019

Disetujui: 17 Juli 2019

\begin{abstract}
The industrial wastewater load pollutant caused without treatment. This study uses a simple technology to reduce the levels of COD, BOD5, and Nitrite by using coffee husk to minimized waters pollution or environmental damage. Adsorbents are activated by $\mathrm{HCl} 0.1 \mathrm{~N}$ and carbonized with muffle furnance to enlarge the surface area of the sorbent and to absorb the contaminants in the effluent of tofu industry. Tofu wastes containing COD, BOD5 and Nitrite contacted with activated carbon with varying weight of $0.2,0.3,0.4 \mathrm{gr}$ and different stirring times 10, 20, 30, 40, 50, 60 minutes and $125 \mathrm{rpm}$ stirring speed with biosorbent size 80-100 mesh. The stirring time 10-30 minutes with the average concentration absorbed for BOD5 > $180 \mathrm{mg} / \mathrm{l}, \mathrm{COD}>650 \mathrm{mg} / \mathrm{l}$ and NO2- $>20 \mathrm{mg} / \mathrm{l}$ and increasing the mass of biosorbent can increase the concentrasion of adsorption. The efficiency absorption of wastewater absorbs more BOD5 than COD and Nitrite with BOD5 absorption efficiency is $85.38 \%$. Adsorption of BOD5, COD and Nitrite follows Langmuir's isotherm equation with R2 value is 0,8104 for BOD5, 0,7121 for COD and 0,7467 for nitrite
\end{abstract}

Keywords: Nitrite, Adsorption, Coffee Husk, COD, BOD

\begin{abstract}
Abstrak
Penelitian ini menggunakan teknologi sederhana untuk menurunkan kadar COD, BOD, dan Nitrit dengan menggunakan ampas kopi untuk meminimalkan pencemaran perairan atau kerusakan lingkungan. Dengan adsorben yang diaktivasi oleh $\mathrm{HCl} 0.1 \mathrm{~N}$ dan dikarbonisasi menggunakan muffle furnance didapatkan luas permukaan dari adsorben menjadi besar hingga adsorben mampu menyerap zat pencemar yang ada didalam limbah cair industri tahu. Limbah tahu yang terkandung COD, BOD5 dan Nitrit dikontakkan dengan biosorben arang aktif dengan memvariasikan berat yaitu $0,2,0,3$ dan 0,4 gr serta lama waktu pengadukan berbeda-beda 10, 20, 30, 40, 50, 60 menit dan kecepatan pengadukan 25rpm, dengan ukuran biosorben 80-100 mesh. Rentang waktu pengadukan 10 - 30 menit konsentrasi rata-rata yang terserap BOD5 $>180 \mathrm{mg} / 1$, COD $>650 \mathrm{mg} / \mathrm{l}$ sedangkan NO2- $>20 \mathrm{mg} / \mathrm{l}$ dan semakin banyak biosorben maka konsentrasi penyerapan akan semakin besar. Efisiensi penyerapan pada limbah Cair Industri Tahu cenderung lebih menyerap kadar BOD5 dibandingkan COD dan Amoniak dengan efesiensi penyerapan NO2- sebesar 85,38\%. Adsorpsi BOD5, COD dan NO2- mengikuti persamaan isoterm Langmuir dengan nilai R2 adalah 0,8104 untuk BOD5, 0,7121 untuk COD dan 0,7467 untuk $\mathrm{NO} 2-$
\end{abstract}

Kata Kunci: NO2, Adsorbsi, Ampas Kopi, COD, BOD

\section{Pendahuluan}

Pencemaran merupakan masalah yang timbul akibat dari berbagai aktivitas manusia termasuk di dalamnya proses industri atau pabrik. Salah satunya adalah pabrik tahu yang ada di kota banda aceh yang mencemari aliran sungai. Beban pencemar tinggi dalam limbah cair industri tahu mengandung padatan tersuspensi maupun terlarut mengalami perubahan fisik, kimia dan hayati yang akan mengasilkan zat pencemar atau toksin terhadap lingkungan dan jika dibiarkan dapat menimbulkan pencemaran udara dari bau tak sedap yang dihasilkan (Nurhasan dan Pramudyanto, 1997)

Pengurangan BOD dan COD dari limbah cair industri tahu dengan memanfaatkan karbon aktif kulit singkong mentega menunjukkan bahwa pada massa karbon aktif kulit singkong 0 gr (kontrol) masing 

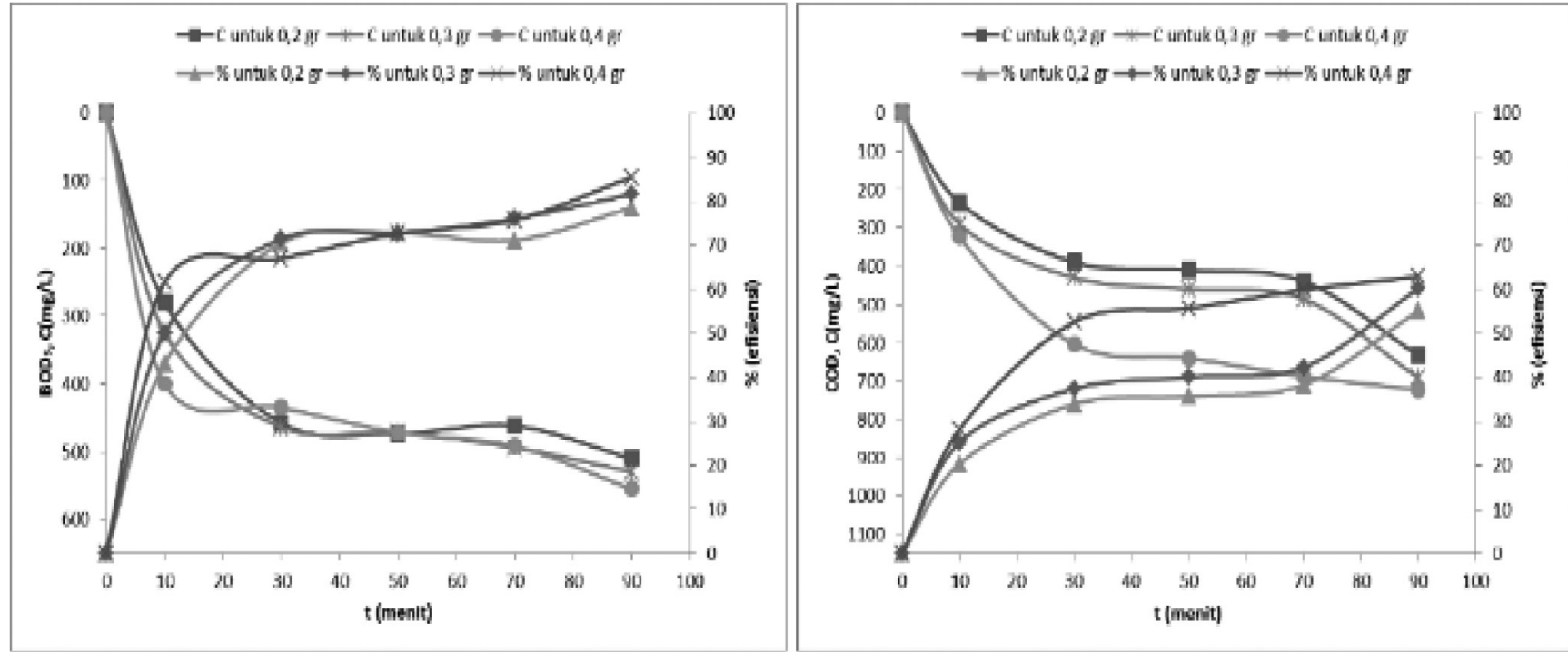

a

b

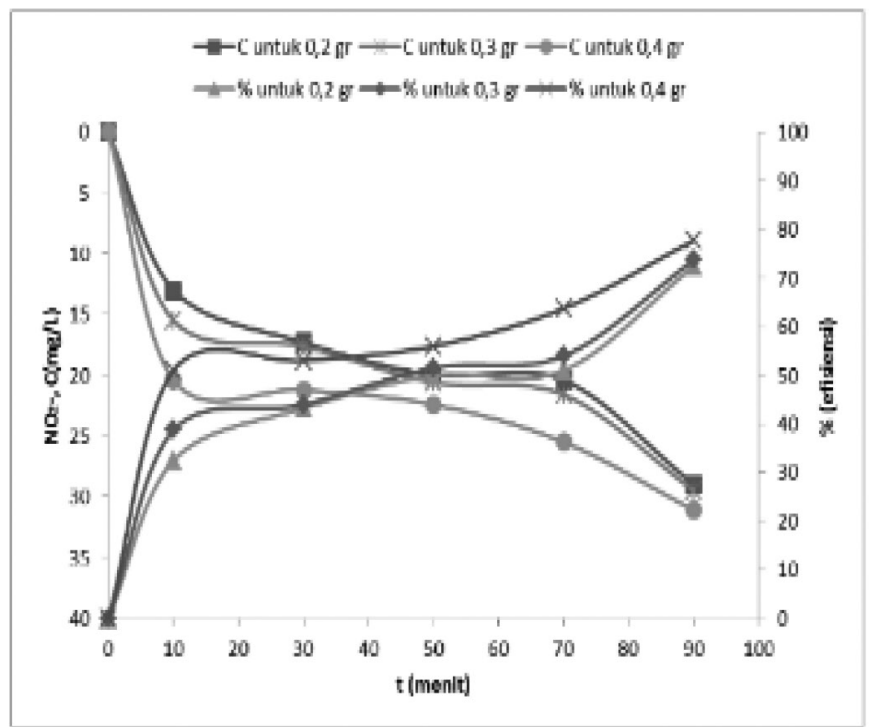

Gambar 1. Pengaruh waktu kontak (t) terhadap Efisiensi (\%) serta Konsentrasi (C): (a).BOD,(b). $\mathrm{COD}^{\text {dan }}(\mathrm{c})$. $\mathrm{NO}_{2}{ }^{-}$ terserap biosorben dari limbah cair industri tahu pada berbagai variasi berat biosorben

masing diketahui 1157 dan 2187 mg/l. Sedangkan untuk massa karbon aktif singkong mentega 3,5 gr yaitu 539 dan 1050 mg/l (Taib, Hiola dan Kadir, 2015)

Penelitian untuk menurunkan kandungan amonia, nitrit dan nitrat dalam limbah cair industri tahu yang memanfaatkan arang aktif dari ampas kopi dengan waktu kontak 30 menit dan $\mathrm{pH}$ optimum 7 diperoleh konsentrasi amonia 64,69\%; nitrit 52,35\%; dan nitrat $86,40 \%$. Pemanfaatan arang aktif dari ampas kopi untuk menurunkan persentase BOD, COD dan TSS limbah cair industri tapioka masing masing diperoleh $33,51 \%, 78,98 \%$ dan $61,05 \%$ pH dan waktu kontak maksimum (Irmanto, Suyata dan Zusfahair, 2013).

Penelitian ini mengkaji penurunan BOD COD, dan nitrit pada limbah cair industri tahu secara simultan dengan memanfaatkan ampas bubuk kopi.

\section{Studi Kepustakaan}

Berdasarkan Status Lingkungan Hidup tahun 2014 dilaporkan bahwa air sungai Kr. Daroy telah tercemar dengan ditemukan tingginya nilai nitrit. Konsentrasi nitrit pada air Kr. Daroy ditemukan rata-rata berkisar 0,097 mg/L (Laporan Status Lingkungan Hidup Daerah Provinsi Aceh, 2014). Limbah industri tahu 


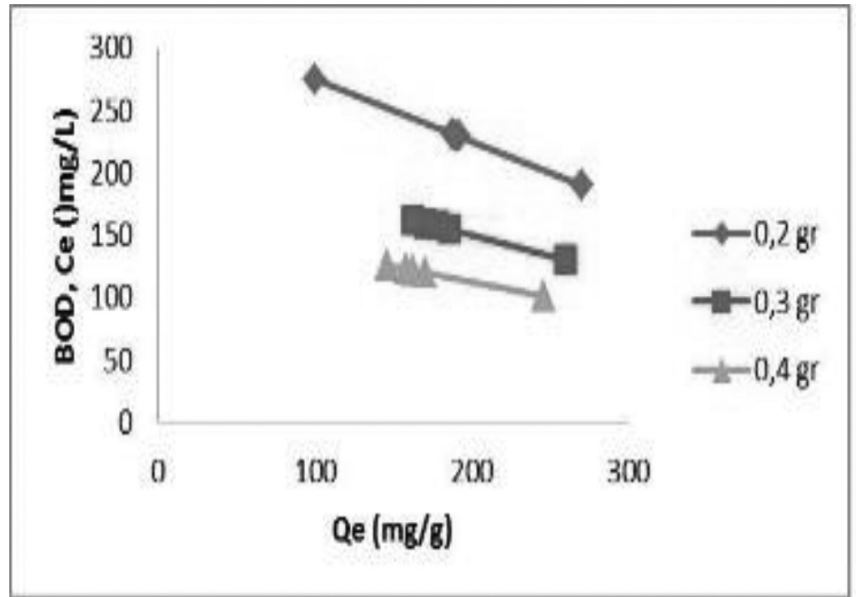

(a)

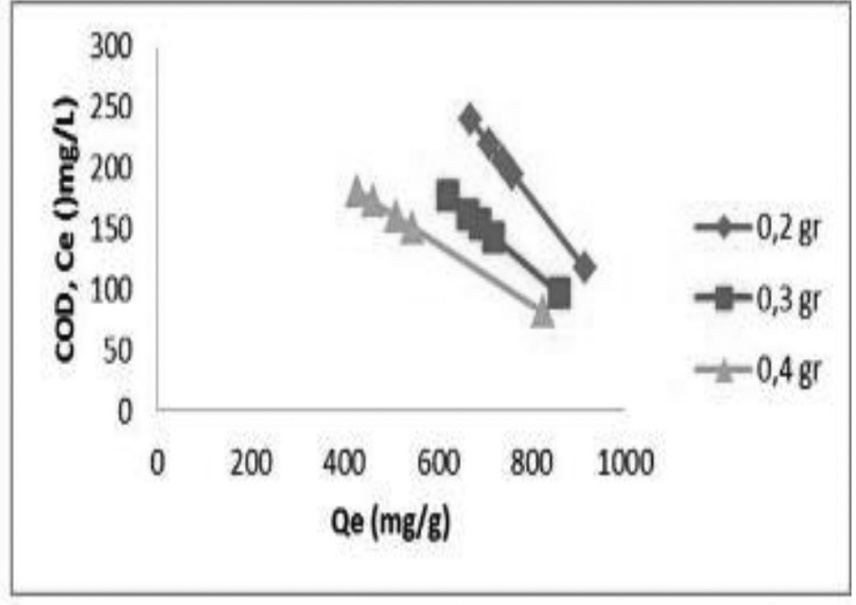

(b)

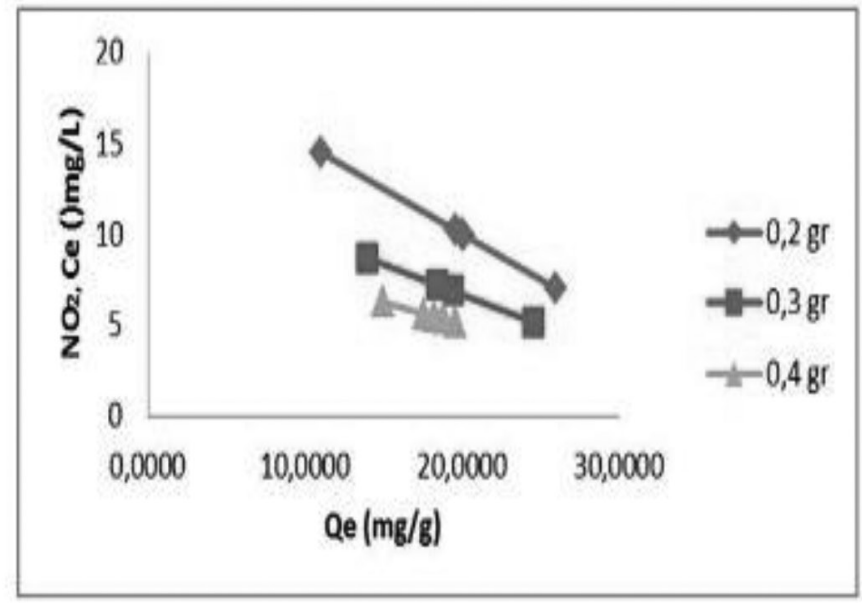

(c)

Gambar 2. Kapasitas Penyerapan (Qe) terhadap Konsentrasi akhir (Ce) Konsentrasi (a). BOD,(b). COD dan (c). $\mathrm{NO}_{2}$ yang tidak terserap biosorben dari limbah cair industri tahu

yang mengandung bahan organik pada konsentrasi tinggi serta tanpa pengolahan dan langsung dibuang kelingkungan perairan akan menimbulkan pencemaran (Nurhasan dan Pramudyanto, 1997)

Arang aktif dapat dibuat dari bahan baku orgnik karena mengandung karbon. Padatan berpori yang dihasilkan dari pemanasan bahan yang mengandung karbon pada suhu tinggi disebut Arang Aktif. Kemampuan adsorbsi semakin tinggi jika permukaan arang aktif semakin luas (Sembiring dan Sinaga, 2003). waktu optimum arang aktif mengadsorb limbah cair pada industri tahu menggunakan Abu Kulit Kapuk dengan variasi waktu 120, 90, 30 menit dan efisiensi penyerapan masing-masing untuk Amonia, Nitrat, serta nitrit yaitu $76 \%, 35,16 \%$ dan 74,6\% (Khofianida, dkk, 2015).
Nitrit didalam tanah secara alami merupakan akibat dari oksidasi mikroba yang berasal dari bahanbahan organik dan juga dapat terbentuk dari limbah buangan industri. Kandungan nitrit $\left(\mathrm{NO}_{2}\right)$ dalam badan air sangat mempengaruhi kualitas dari badan air. Pada badan air jika dibandingkan reaksi-reaksi biokimia yang terjadi, maka siklus nitrogen mengkonsumsi paling banyak oksigen terlarut (Aswadi, 2006).

Aktivasi secarafisikamenghasilkankarbondengan struktur pori yang halus, sehingga baik menyerap senyawa dalam fase cair dan uap. Aktivasi secara kimia, biasanya menghasilkan karbon dengan struktur pori yang lebih terbuka, sehingga ideal untuk menyerap molekul yang lebih besar (Boonamnuayvitaya, Saeung dan Tanthapanichakoon, 2005). 
Peristiwa adsorpsi pada karbon aktif pada umumnya terjadi pada pori partikel bagian dalam, adsorpsi intra partikel atau adsorpsi mikropori dan adsorpsi pada bagian luar partikelnya, adsorpsi ekstra partikel dapat diabaikan (Bastian Arifin, 2002).

Kinetika adsorpsi digunakan untuk mengetahui tingkat kecepatan (laju) penyerapan bioadsorben terhadap adsorbat. Laju penyerapan ini ditentukan dengan memvariasikan waktu kontak adsorpsi. Untuk menentukan kinetika adsorpsi dapat menggunakan model kinetika orde satu dan dua yang semu. Perhitungan kinetika dilakukan pada konsentrasi dan kapasitas adsorpsi optimum.

Hubungan kesetimbangan konsentrasi dalam adsorben dan konsentrasi fasa fluida pada temperatur tertentu disebut Isoterm Adsorpsi. Isotermal Adsorpsi dapat digunakan untuk meninjau mekanisme adsorpsi
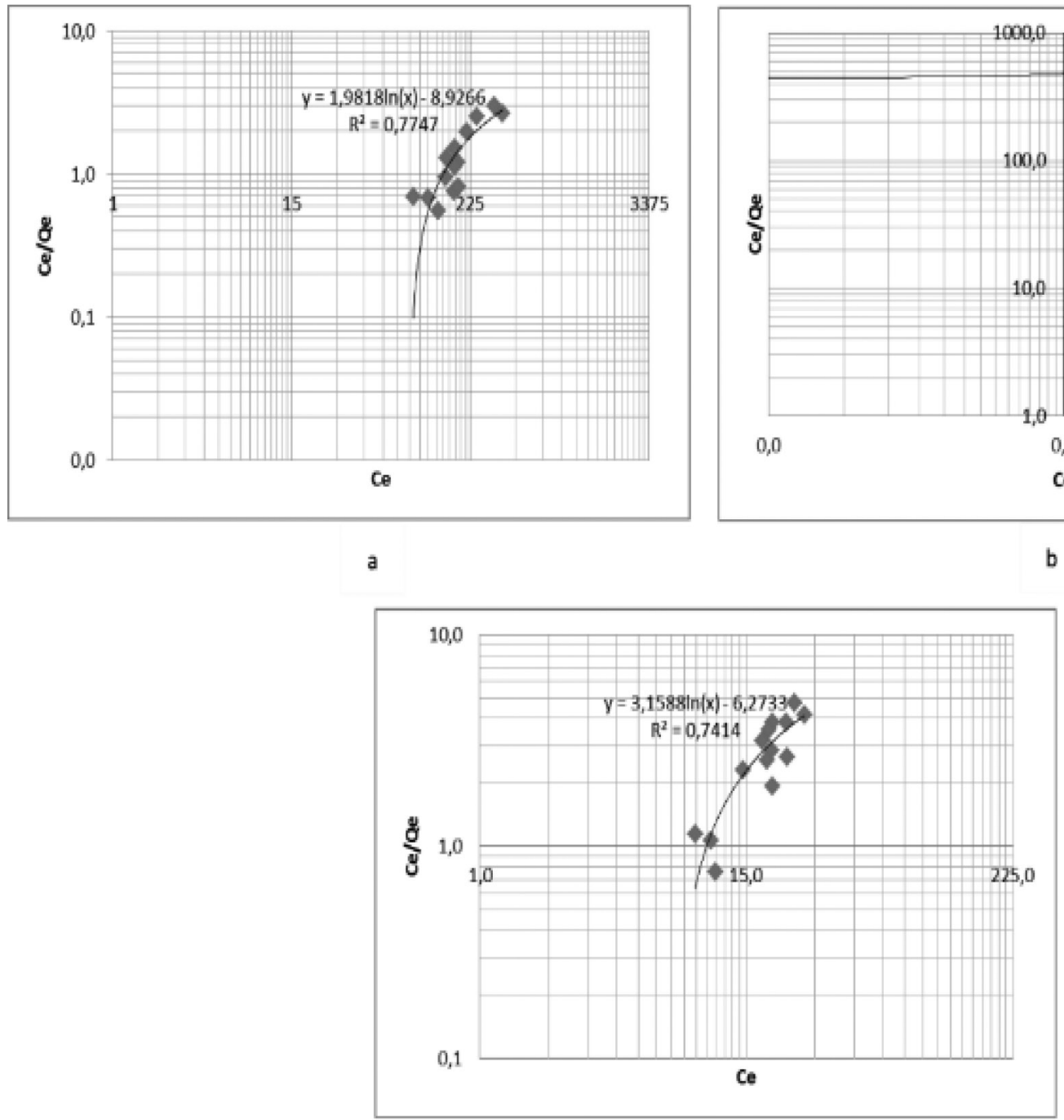

suatu zat. Beberapa tipe isoterm adsorpsi dikembangkan guna mendeskripsikan interaksi antara adsorbat dan adsorben. tipe isoterm Langmuir dan Freundlich umumnya digunakan untuk menggambarkan fenomena adsorpsi padat-cair (Diapati, 2009).

\subsection{Metodologi Penelitian}

\subsubsection{Alat-alat yang Digunakan}

Muffle furnace, ayakan mekanis 80-100 Mesh, Neraca analitik, Spektrofotometer UV-Visible, Stirrer hot plate, Desikator, Kertas saring, $\mathrm{pH}$ meter, Oven listrik, Scanning Electron Microscope (SEM), Magnetic Stirrer, Gelas ukur $500 \mathrm{ml}$, Gelas kimia $500 \mathrm{ml}$.

\subsubsection{Bahan-bahan yang digunakan}

Ampas bubuk kopi, limbah cair dari industri tahu yang ada di kecamatan Banda Raya , larutan $\mathrm{HCl} 38 \%$ $0,1 \mathrm{M}$, larutan $\mathrm{Na}_{2} \mathrm{~S}_{2} \mathrm{O}_{3} 98 \% 0,1 \mathrm{~N}$, larutan $\mathrm{NaOH}$

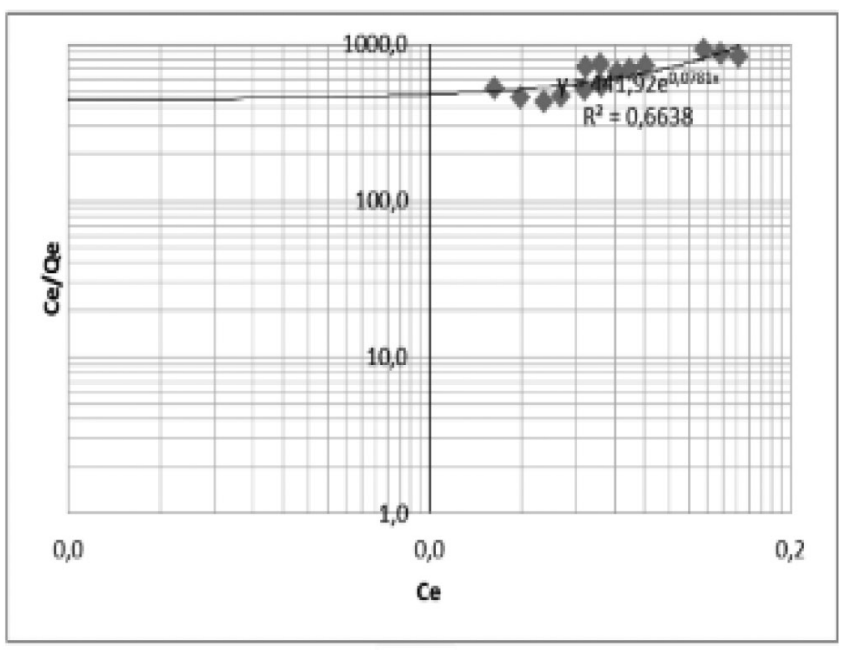

b

Gambar 3. Isothermal Langmuir untuk (a). $\mathrm{BOD}$,(b). COD dan (c). $\mathrm{NO}_{2}$ 


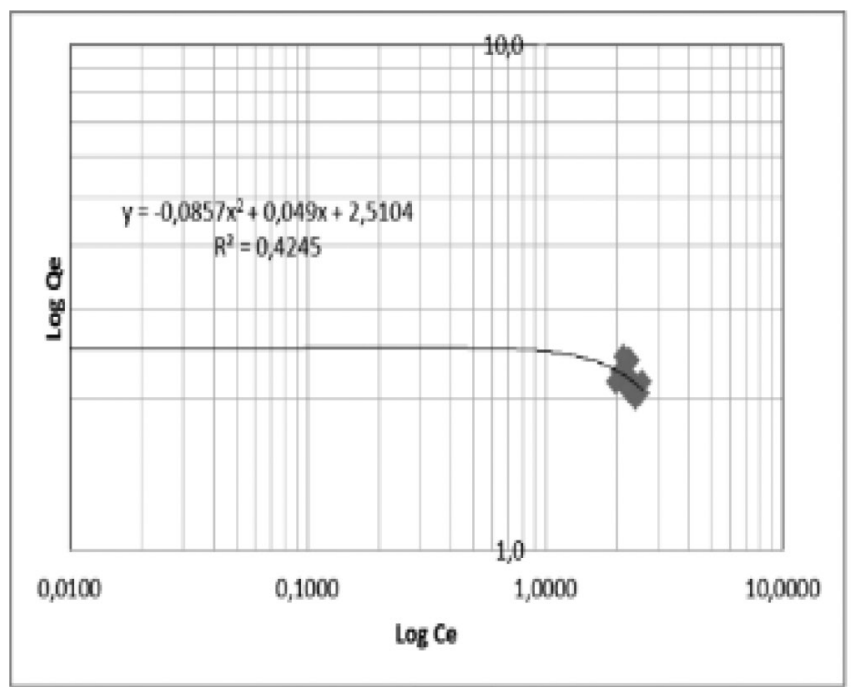

a

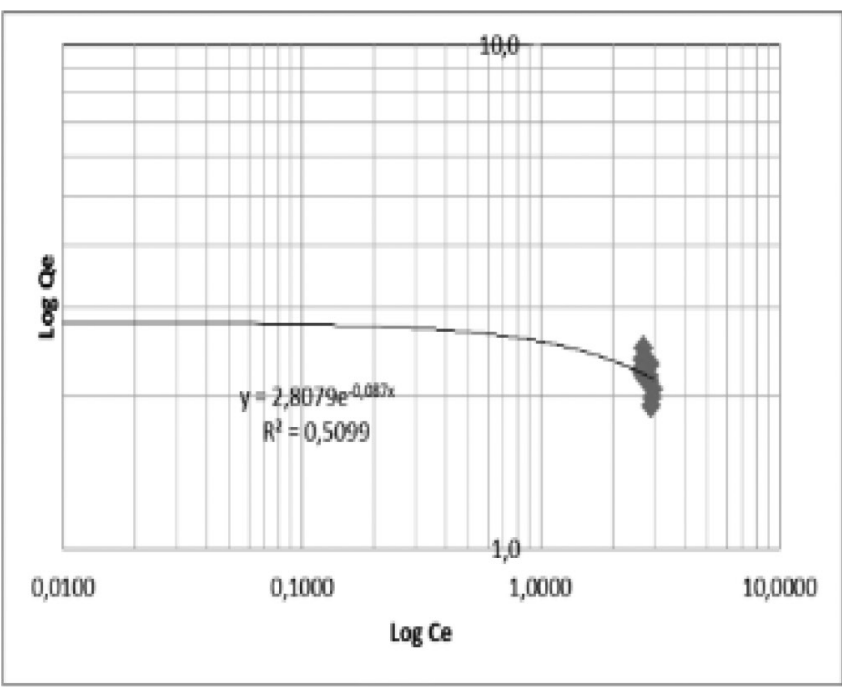

b

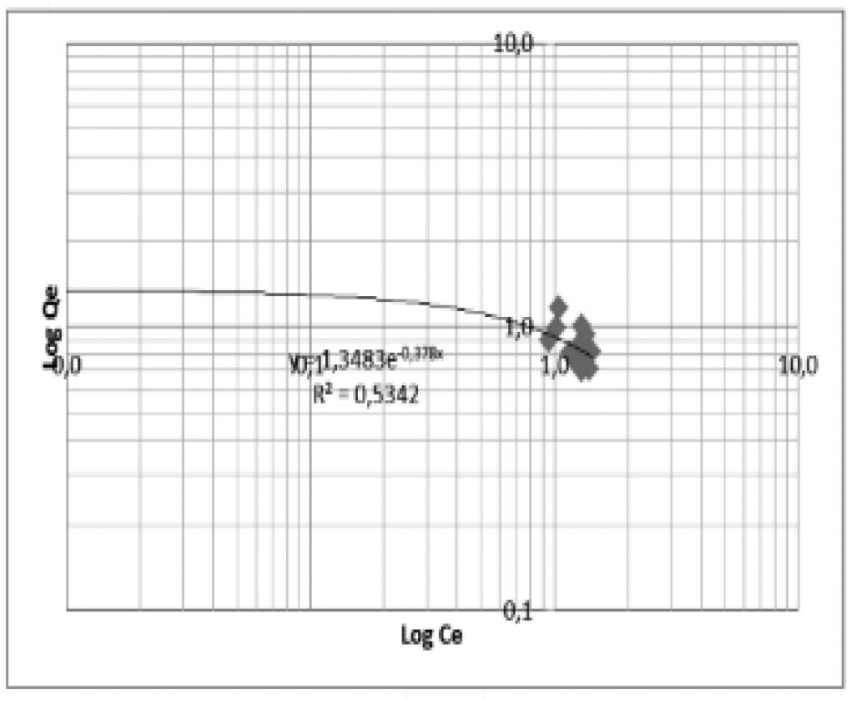

c

Gambar 4. Grafik Isothermal Freundlich untuk (a). BOD,(b). COD dan (c). $\mathrm{NO}_{2}$

98\% 0,1 N , Methylene Blue, Aquades, $\mathrm{KNO}_{3}, \mathrm{NaNO}_{2}$

\subsection{Prosedur Penelitian}

Percobaan yang akan dilakukan pada tahap I adalah persiapan biosorben arang aktif ampas kopi. Sedangkan tahap II adalah proses penyerapan nitrit menggunakan proses batch.

\subsubsection{Prosedur Persiapan Arang Aktif Ampas Bubuk Kopi}

Ampaskopi yang telah dikeringkan direndam selama 48 jam dengan $\mathrm{HCl}$ 0,1 M yang berfungsi sebagai larutan pengaktif (Irmanto dan Suyata, 2009). Setelah ditiriskan, diicuci dengan aquades sampai pH netral. Ampas kopi yang telah diaktivasi dioven untuk mengurangi kadar airnya terlebih dahulu, selanjutnya dibakar dalam muffle furnace selama 3,5 jam dengan suhu $350^{\circ} \mathrm{C}$. Kemudian disimpan dalam desikator setelah proses pengarangan dan pengayakan dengan ayakan 80 -100 mesh.

\subsubsection{Penyerapan COD, BOD dan Nitrit Pada Proses Batch}

Limbah tahu yang mengandung COD, BOD dan Nitrit sebanyak $100 \mathrm{ml}$ dikontakkan dengan biosorben arangk aktif dengan berat yang berbedabeda yaitu $0,2 \mathrm{gr}, 0,3 \mathrm{gr}$, dan $0,4 \mathrm{gr}$ selanjutnya diaduk dengan waktu pengadukan yang bervariasi yaitu 10 , 20, 30, 40, 50, 60 menit dan kecepatan pengadukan 25rpm dengan ukuran biosorben 80-100 mesh. Kadar COD, BOD dan Nitrit dalam Limbah diukur dengan 
Spektrofotometri baik sebelum maupun sesudah dikontakkan dengan arang aktif sedangkan untuk cake sebelum dan sesudah aktivasi serta penyerapan dianalisis dengan SEM.

\section{Hasil dan Pembahasan}

\subsection{Karakteristik Ampas Kopi}

Arang aktif ampas kopi adalah karbon yang di proses sedemikian rupa dengan menggunakan alat furnance dengan suhu $350^{\circ} \mathrm{C}$ agar pori - pori terbuka, sehingga berdaya serap yang tinggi. Arang aktif memiliki permukaan dalam (internal surface) dan daya serap yang baik sebagai karbon bebas .

\subsubsection{Pengaruh Waktu Terhadap Efisiensi serta konsentrasi penyerapan BOD, $\mathrm{COD}$ dan $\mathrm{NO}_{2}$}

Efisiensi Penyerapan dan pengakumulasian $\mathrm{BOD}_{5}$, COD serta $\mathrm{NO}_{2}^{-}$yang terkandung dalam limbah tahu oleh arang aktif dari ampas bubuk kopi dapat dilihat dari jumlah biosorben serta waktu kontak terhadap konsentrasi yang terserap dari air limbah. Pengaruh waktu terhadap efisiensi penyerapan $\mathrm{BOD}_{5}$, COD dan $\mathrm{NO}_{2}^{-}$dan tampak pada Gambar 1.

Gambar 1. memperlihatkan bahwa konsentrasi $\mathrm{BOD}_{5}$ yang terserap secara signifikan terjadi pada waktu kontak 10 dan 30 menit pada masing-masing berat biosorben yaitu 280 dan $458 \mathrm{mg} / 1$ untuk 0,2 gr, 325 dan $464 \mathrm{mg} / 1$ untuk 0,3 gr serta 400 dan 435 $\mathrm{mg} / 1$ untuk 0,4 gr. Sedangkan konsentrasi COD yang terserap secara signifikan terjadi pada waktu kontak 10 dan 30 menit dengan konsentrasi COD pada masing masing berat yaitu $234 \mathrm{mg} / \mathrm{L}$ dan $390 \mathrm{mg} / \mathrm{L}$ untuk $0,2 \mathrm{gr}, 290 \mathrm{mg} / \mathrm{L}$ dan $430 \mathrm{mg} / \mathrm{L}$ untuk $0,3 \mathrm{gr}$ serta $324 \mathrm{mg} / \mathrm{L}$ dan $604 \mathrm{mg} / \mathrm{L}$ untuk 0,4 gr. Dan $\mathrm{NO}_{2}{ }^{-}$ yang terserap secara signifikan terjadi pada waktu kontak 10 dan 30 menit dengan konsentrasi $\mathrm{NO}_{2}{ }^{-}$pada masing masing berat yaitu 13 dan $17,30 \mathrm{mg} / 1$ untuk 0,2 gr, 15,50 dan 17,60 mg/l untuk 0,3 gr serta 20,40 dan $21,20 \mathrm{mg} / 1$ untuk 0,4 gr. Sedangkan pada waktu kontak 50, 70 dan 90 terlihat $\mathrm{BOD}_{5}, \mathrm{COD}$ dan $\mathrm{NO}_{2}$ cenderung terserap tidak dalam jumlah yang besar, dan jumlah biosorben mempengaruhi konsentrasi yang terserap, semakin banyak biosorben maka konsentrasi dan efisiensi penyerapan pun akan semakin besar.

Secara umum Pengaruh waktu terhadap konsentrasi dari Gambar 1 diketahui bahwa pada rentang waktu 10 menit pertama penyerapan terjadi secara linier yang menandakan bahwa proses biosorpsi berlangsung baik, sedangkan pada menit-menit selanjutnya proses biosorpsi yang terjadi cenderung konstan dan semakin lama waktu kontak maka jumlah adsorbat yang terserap akan semakin kecil yang dikarenakan biosorben semakin mendekati jenuh dan pori-pori dari biosorben telah terisi dengan adsorbat.

\subsubsection{Pengaruh Kapasitas penyerapan terhadap Konsentrasi akhir BOD, COD dan $\mathrm{NO}_{2}$}

Kapasitas penyerapan (Qe) sangat dipengaruhi oleh konsentrasi adsorbat yang tertinggal dalam larutan limbah setelah dikontakkan dengan biosorben dalam waktu tertentu. Berikut gambar pengaruh kapasitas penyerapan terhadap konsentrasi akhir BOD, COD dan $\mathrm{NO}_{2}$.

Gambar 2 memperlihakan bahwa konsentrasi BOD, COD dan $\mathrm{NO}_{2}$ yang tidak terserap menunjukkan penurunan secara teratur dengan perbedaan massa biosorben 0,2, 0,3 dan 0,4 gr. Dengan efektifitas penyerapan semakin besar maka konsentrasi larutan semakin besar, jumlah zat terlarut semakin banyak yang dapat diadsorpsi sehingga keseimbangan tercapai, dimana laju zat yang diserap sama dengan zat yang dilepas dari adsorben pada suhu tertentu (Handayani dan Sulistiyono, 2009)

\subsubsection{Isotermal Langmuir dan Freundlich}

Isoterm adsorpsi merupakan suatu hal yang fundamental untuk dapat menentukan kapasitas maksimum dari adsorben, yaitu dengan melihat fungsi konsentrasi yang zat terlarut terserap padatan terhadap konsentrasi larutan. Guna menggambarkan hubungan adsorben dan zat teradsorp pada kesetimbangan tertentu digunakan Isoterm Adsorpsi (Krisdiyanto dan Nugraha, 2014).

Isoterm adsorpsi Langmuir BOD, COD dan Nitrit didapat dengan membuat kurva konsentrasi kesetimbangan fasa cair (Ce) terhadap kesetimbangan fasa padat $\left(\mathrm{Ce} / \mathrm{q}_{\mathrm{e}}\right)$. Untuk menentukan kapasitas adsorpsi dari adsorben ampas kopi dengan menggunakan perhitungan persamaan linier dari grafik isoterm Langmuir dan Freundlich. Isotherm langmuir untuk BOD, COD dan Nitrit masing-masing terlihat pada Gambar 3. 
Pada Gambar 3. terlihat dapat dilihat nilai $\mathrm{R}^{2}$ dari isotherm langmuir BOD yaitu $\mathrm{R}^{2}=0,7747$, COD yaitu $\mathrm{R}^{2}=0,6638, \mathrm{NO}_{2}$ yaitu $\mathrm{R}^{2}=0,7414$. Penentuan isoterm adsorpsi Freundlich diperoleh dengan membuat hubungan antara log Ce dengan log Qe. Isoterm Freundlich menggambarkan hubungan antara sejumlah komponen yang teradsorpsi per unit adsorben dan konsentrasi adsorbat pada kesetimbangan (Apriliani, 2010)

Pada Persamaan isotherm Freundlich, jenis ikatan yang terbentuk tidak sama dan energi serta situs aktif pada permukaan adsorben beragam. Dan adsorpsi terjadi secara multilayer pada permukaan adsorben (Langenati, Mustika dan Wasito, 2012). Proses adsorpsi terjadi dibawah kondisi pada semua sisi permukaan sorben. Selain itu pada saat kesetimbangan dicapai persamaan isotherm Freundlich tidak mampu memperkirakan sisi permukaan yang dapat mencegah adsorpsi dan kemampuan adsorpsi molekul terlarut hanya terjadi pada beberapa sisi aktif (Apriliani, 2010) Isotherm Freundlich untuk BOD, COD dan Nitrit terlihat pada Gambar 4.

Pada Gambar 4. terlihat dapat dilihat nilai $\mathrm{R}^{2}$ dari isotherm Freundlich BOD yaitu $\mathrm{R}^{2}=0,4245$, COD yaitu $\mathrm{R}^{2}=0,5099$, dan $\mathrm{NO}_{2}$ yaitu $\mathrm{R}^{2}=0,5342$. Pola isotherm Freundlich mengamsusikan bahwa interaksi yang terjadi adalah secara fisika. Isoterm Freundlich juga menjelaskan bahwa potensi penyerapan berbeda pada tiap molekul dan mempunyai permukaan adsorben yang beragam, dimana tidak semua permukaan adsorben mempunyai daya adsorpsi yang sama (Krisdiyanto dan Nugraha, 2014). Sehingga dapat digambarkan bahwa adsorbsi yang terjadi antara BOD, COD dan nitrit pada permukaan arang akif ampas kopi memiliki ikatan yang lemah dan heterogen karena permukaan adsorben yang kurang seragam.

\section{Kesimpulan}

Berdasarkan hasil penelitian dapat disimpulkan sebagai berikut :

1. Pada rentang waktu pengadukan 10 - 30 menit konsentrasi rata-rata yang terserap untuk BOD $>180 \mathrm{mg} / \mathrm{L}, \mathrm{COD}>650 \mathrm{mg} / \mathrm{L}$ dan $\mathrm{NO}_{2}>20 \mathrm{mg} / \mathrm{L}$ dan semakin banyak biosorben maka konsentrasi penyerapan akan semakin besar

2. Efesiensi penyerapan pada limbah Cair Industri Tahu cenderung lebih menyerap kadar BOD dibandingkan $\mathrm{COD}$ dan $\mathrm{NO}_{2}$ dengan efisiensi penyerapan amoniak sebesar $85,38 \%$

3. Adsorpsi $\mathrm{BOD}, \mathrm{COD}$ dan $\mathrm{NO}_{2}$ mengikuti persamaan isoterm Langmuir dengan nilai $\mathrm{R}^{2}$ adalah 0,7747 untuk BOD, 0,6638 untuk COD dan 0,7414 untuk $\mathrm{NO}_{2}$.

\section{Daftar Pustaka}

Apriliani, A. (2010) 'Pemanfaatan arang ampas tebu sebagai adsorben ion logam $\mathrm{Cd}, \mathrm{Cr}, \mathrm{Cu}$ dan $\mathrm{Pb}$ dalam air limbah'. UIN Syarif Hidayatullah Jakarta: Fakultas Sains dan Teknologi, 2010.

Aswadi, M. (2006) 'Pemodelan Fluktuasi Nitrogen (Nitrit) pada Aliran Sungai Palu', SMARTek, 4(2).

Bastian Arifin (2002) Adsorpsi Merkuri Dalam Air Oleh Partikel Kayu. Institut Teknologi Bandung.

Boonamnuayvitaya, V., Sae-ung, S. and Tanthapanichakoon, W. (2005) 'Preparation of Activated Carbons from Coffee Residue for the Adsorption of Formaldehyde', Separation and Purification Technology, 42(2), pp. 159-168. doi: https://doi.org/10.1016/j. seppur.2004.07.007.

Diapati, M. (2009) 'Ampas Tebu sebagai Adsorben Zat Warna Reaktif Cibacron Red', Jurnal [Online]. http://repository. ipb. ac. id/bitstream/ handle/123456789/14831/G09mdi. pdf (diakses pada 09 April 2015).

Handayani, M. and Sulistiyono, E. (2009) 'Uji Persamaan Langmuir dan Freundlich pada Penyerapan Limbah Chrom (VI) oleh Zeolit', in Prosiding Seminar Nasional Sains dan Teknologi Nuklir PTNBR-BATAN, pp. 130-136.

Irmanto, I. and Suyata, S. (2009) 'Penurunan kadar amonia, nitrit, dan nitrat limbah cair industri tahu menggunakan arang aktif dari ampas kopi', Molekul, 4(2), pp. 105-114.

Irmanto, I., Suyata, S. and Zusfahair, Z. (2013) 'Optimasi Penurunan COD, BOD, Dan TSS Limbah Cair Industri Etanol (Vinasse) PSA Palimanan Dengan Metode Multi Soil Layering (MSL)', Molekul, 8(2), pp. 131-141.

Khofianida, Elok; Ratnani, Rita Dwi; Khasanah, Sufrotun; Miningsih, Nanik Andar; Fikriyyah, N. (2015) 'Pemanfaatan Limbah Padat Sisa 
Pembakaran Sebagai Adsorpsi Limbah Cair Pada Pabrik Tahu', Prosiding SNST Fakultas Teknik, 1(1).

Krisdiyanto, D. and Nugraha, K. I. (2014) 'Sintesis

Zeolit Dari Abu Dasar Batubaradan Aplikasinya Sebagai Adsorben Logam Merkuri (II)', Molekul, 9(1), pp. 73-83.

Langenati, R., Mustika, D. and Wasito, B. (2012) 'Pengaruh Jenis Adsorben Dan Konsentrasi Uranium Terhadap Pemungutan Uranium Dari Larutan Uranil Nitrat', Jurnal Teknologi Bahan Nuklir, 8(2).

Laporan Status Lingkungan Hidup Daerah Provinsi Aceh (2014).

Nurhasan, A. and Pramudyanto, B. B. (1997) 'Pengolahan Air Buangan Tahu', Semarang: Yayasan Bina Karta Lestari dan Wahana Lingkungan Hidup Indonesia.

Sembiring, M. T. and Sinaga, T. S. (2003) 'Arang Aktif (pengenalan dan proses pembuatannya)'. Taib, L., Hiola, R. and Kadir, S. (2015) 'Uji Efektifitas Karbon Aktif Kulit Singkong Mentega (Manihot Esculenta) Dalam Menurunkan Kadar BOD Dan COD Limbah Cair Tahu', KIM Fakultas Ilmu Kesehatan dan Keolahragaan, 3(1). 